\title{
Antifungal Activity of Extracts, Fractions, and Constituents from Coccoloba cowellii Leaves
}

\author{
Daniel Méndez ${ }^{1}$ (D) Julio C. Escalona-Arranz ${ }^{2, *}$, Enrique Molina Pérez ${ }^{1}$, Kenn Foubert ${ }^{3}$, An Matheeussen ${ }^{4}$ (D), \\ Emmy Tuenter ${ }^{3}\left(\mathbb{D}\right.$, Ann Cuypers ${ }^{5}$ (D), Paul $\operatorname{Cos}^{4}$ and Luc Pieters ${ }^{3, *(D)}$
}

1 Chemistry Department, Faculty of Applied Sciences, University of Camagüey, Carretera de Circunvalación Km 5 $\frac{1}{2}$, Camagüey 74650, Cuba; daniel.mendez@reduc.edu.cu (D.M.); enrique.molina@reduc.edu.cu (E.M.P.)

2 Pharmacy Department, Faculty of Natural and Exact Sciences, Universidad de Oriente, Avenida Patricio Lumumba s/n, Santiago de Cuba 90500, Cuba

3 Natural Products \& Food Research and Analysis (NatuRA), Department of Pharmaceutical Sciences, University of Antwerp, Universiteitsplein 1, BE-2610 Antwerp, Belgium; kenn.foubert@uantwerpen.be (K.F.) emmy.tuenter@uantwerpen.be (E.T.)

4 Laboratory of Microbiology, Parasitology and Hygiene (LMPH), Faculty of Pharmaceutical, Biomedical and Veterinary Sciences, University of Antwerp, Universiteitsplein 1, BE-2610 Antwerp, Belgium; an.matheeussen@uantwerpen.be (A.M.); paul.cos@uantwerpen.be (P.C.)

5 Centre for Environmental Sciences, Campus Diepenbeek, Hasselt University, Agoralaan Building D, BE-3590 Diepenbeek, Belgium; ann.cuypers@uhasselt.be

* Correspondence: jcea@uo.edu.cu (J.C.E.-A.); luc.pieters@uantwerpen.be (L.P.)

\section{check for}

updates

Citation: Méndez, D.;

Escalona-Arranz, J.C.; Pérez, E.M.;

Foubert, K.; Matheeussen, A.; Tuenter,

E.; Cuypers, A.; Cos, P.; Pieters, L.

Antifungal Activity of Extracts,

Fractions, and Constituents from

Coccoloba cowellii Leaves.

Pharmaceuticals 2021, 14, 917. https://

doi.org/10.3390/ph14090917

Academic Editors: Dejan Stojković and Marina Sokovic

Received: 23 August 2021

Accepted: 8 September 2021

Published: 10 September 2021

Publisher's Note: MDPI stays neutral with regard to jurisdictional claims in published maps and institutional affiliations.

Copyright: (c) 2021 by the authors. Licensee MDPI, Basel, Switzerland. This article is an open access article distributed under the terms and conditions of the Creative Commons Attribution (CC BY) license (https:// creativecommons.org/licenses/by/ $4.0 /)$.

\begin{abstract}
Coccoloba cowellii Britton (Polygonaceae, order Caryophyllales) is an endemic and critically endangered plant species that only grows in the municipality of Camagüey, a province of Cuba. A preliminary investigation of its total methanolic extract led to the discovery of promising antifungal activity. In this study, a bioassay-guided fractionation allowed the isolation of quercetin and four methoxyflavonoids: 3-O-methylquercetin, myricetin 3,3' ,4'-trimethyl ether, 6-methoxymyricetin $3,4^{\prime}$-dimethyl ether, and 6-methoxymyricetin 3,3',4'-trimethyl ether. The leaf extract, fractions, and compounds were tested against various fungi and showed strong in vitro antifungal activity against Cryptococcus neoformans and various Candida spp. with no cytotoxicity $\left(\mathrm{CC}_{50}>64.0 \mu \mathrm{g} / \mathrm{mL}\right)$ on MRC-5 SV2 cells, determined by a resazurin assay. A Candida albicans SC5314 antibiofilm assay indicated that the antifungal activity of $C$. cowellii extracts and constituents is mainly targeted to planktonic cells. The total methanolic extract showed higher and broader activity compared with the fractions and mixture of compounds.
\end{abstract}

Keywords: Coccoloba cowellii; Polygonaceae; UHPLC-ESI-QTOF-MS; methoxyflavonoids; antifungal

\section{Introduction}

Fungal infections represent a major health problem, with mortality rates comparable to those of tuberculosis or malaria, estimated at 1.5 million individuals per year [1] The growing number of immunocompromised individuals due to the increase of organ transplantation, the prevalence of cancer and AIDS patients, and the ageing population have all contributed to this situation [2]. The predominant etiological agents of systemic fungal infections are species of Candida, Aspergillus, and Cryptococcus, representing over $90 \%$ of mycotic deaths [3]. Candida sp. stand out as the most common in the intensive care units, affecting individuals that undergo invasive clinical procedures and/or have experienced significant traumas requiring prolonged treatments [4]. Candida albicans is the most common (50-70\%), producing more infections than all other Candida species combined [5]. C. glabrata is the second most dangerous species, with an increasing number of invasive candidiasis over the past several years [4].

Despite the negative impact that these fungi have on human health, currently, there are only three classes of antifungal agents available to treat serious Candida infections: 
azoles, echinocandins, and polyenes [6]. It is a worrying fact that almost all new approved drugs are based mainly on the old azole core structure [7]. In this context, natural plant derivatives constitute a promising resource available to the scientific community.

In a recent study, the total methanolic extract from the leaves of Coccoloba cowellii showed promissory antifungal activity against $C$. albicans and Cryptococcus neoformans, with $\mathrm{IC}_{50}$ values of $2.1 \mu \mathrm{g} / \mathrm{mL}$ and $4.1 \mu \mathrm{g} / \mathrm{mL}$, respectively [8]. The major constituents of the aforementioned extract were glucuronides and glycosides of myricetin and quercetin; proanthocyanidins (tentatively characterized through HRMS); and epichatechin3-O-gallate, catechin, epicatechin, and gallic acid (tentatively characterized using HRMS and authentic standards) [8]. The abundance of polyphenols in C. cowellii leaves and their recognised activity against fungi were the elements that allowed us to hypothesise that a bioassay-guided fractionation process could be a useful strategy to explore the potential of extracts, fractions, and constituents derived from this plant against a panel of Candida spp., which became the objective of the present work.

\section{Results}

\subsection{Biofractionation Strategy}

The total methanolic extract from C. cowellii leaves (hereafter referred to as total extract) was subjected to bioassay-guided fractionation following the scheme shown in Figure 1. Given the promising results obtained for the total extract [8], the antifungal activity was employed as a guide for the fractionation and isolation of active compounds. Table 1 shows the results of the in vitro antifungal bioassays performed on the total extract and its fractions. Antifungal activity against a secondary panel of fungi (Candida spp. and Aspergillus fumigatus) was only determined when fractions were active against the first panel of fungi (C. neoformans and C. albicans). In general, samples were not active against Aspergillus fumigatus at concentrations of $64 \mu \mathrm{g} / \mathrm{mL}$ or lower. The total extract showed a strong antifungal effect against all strains with the exception of $C$. tropicalis and the previously mentioned A. fumigatus. Only the fraction $\mathrm{MeOH} 90-\mathrm{F}$ showed similar behaviour to the origin extract but with higher $\mathrm{IC}_{50}$ values.

At the same time, we intended to evaluate the selectivity of the antifungal activity using the cytotoxicity on human foetal lung fibroblasts (MRC-5 SV2 cells). None of the fractions showed cytotoxicity except for the $n$-hexane fraction (nH-F). Thus, the selectivity index of the total extract ranged from 160 (for C. glabrata) to 3 (for C. tropicalis), depending on the microorganism susceptibility. The indexes were consequently lowest for the MeOH90-F fraction, with values of 27 and 5 for C. glabrata and C. parapsilosis, respectively, while no activity was found against $C$. tropicalis. Nevertheless, in all cases, these values can be considered acceptable, evidencing a selective action on the microorganism tested.

Only the MeOH90-F fraction displayed significant antifungal activity, and it was thus chosen for further phytochemical characterization.

Table 1. In vitro antifungal and cytotoxic activity of the total extract and fractions from C. cowellii leaves.

\begin{tabular}{|c|c|c|c|c|c|c|c|}
\hline \multirow[t]{2}{*}{ Test Sample } & \multirow{2}{*}{$\begin{array}{c}\begin{array}{c}\text { Cytotoxicity } \\
\left(C^{2} C_{50} \mu \mathrm{g} / \mathrm{mL}\right)\end{array} \\
\text { MRC-5 }\end{array}$} & \multicolumn{6}{|c|}{ Antifungal Screening $\left(\mathrm{IC}_{50} \mu \mathrm{g} / \mathrm{mL}\right)$} \\
\hline & & $\begin{array}{l}\text { Aspergillus } \\
\text { fumigatus }\end{array}$ & $\begin{array}{c}\text { Cryptococcus } \\
\text { neoformans }\end{array}$ & $\begin{array}{l}\text { Candida } \\
\text { albicans }\end{array}$ & $\begin{array}{c}\text { Candida } \\
\text { parapsilosis }\end{array}$ & $\begin{array}{l}\text { Candida } \\
\text { glabrata }\end{array}$ & $\begin{array}{l}\text { Candida } \\
\text { tropicalis }\end{array}$ \\
\hline TE & $>64.0$ & $>64.0$ & $2.7 \pm 2.0$ & $1.7 \pm 0.6$ & $8.5 \pm 0.5$ & $0.4 \pm 0.0$ & $21.2 \pm 1.8$ \\
\hline MeOH90-F & $>64.0$ & $>64.0$ & $10.5 \pm 1.0$ & $8.3 \pm 0.9$ & $13.3 \pm 1.1$ & $2.4 \pm 0.4$ & $>64.0$ \\
\hline $\mathrm{nH}-\mathrm{F}$ & $29.3 \pm 1.5$ & $\mathrm{Nd}$ & $>64.0$ & $>64.0$ & $\mathrm{Nd}$ & $\mathrm{Nd}$ & $\mathrm{Nd}$ \\
\hline EtOAc-F & $>64.0$ & $\mathrm{Nd}$ & $>64.0$ & $>64.0$ & $\mathrm{Nd}$ & $\mathrm{Nd}$ & $\mathrm{Nd}$ \\
\hline nBut-F & $>64.0$ & $\mathrm{Nd}$ & $>64.0$ & $>64.0$ & $\mathrm{Nd}$ & $\mathrm{Nd}$ & $\mathrm{Nd}$ \\
\hline Re-F & $>64.0$ & $\mathrm{Nd}$ & $>64.0$ & $>64.0$ & $\mathrm{Nd}$ & $\mathrm{Nd}$ & $\mathrm{Nd}$ \\
\hline Miconazole & $19.8 \pm 0.7$ & $3.7 \pm 0.5$ & $0.2 \pm 0.0$ & $3.4 \pm 0.2$ & $1.1 \pm 0.1$ & $0.2 \pm 0.0$ & $3.6 \pm 1.0$ \\
\hline
\end{tabular}

TE: total extract; MeOH90-F: methanol 90\% fraction; nH-F: $n$-hexane fraction; EtOAc-F: ethyl acetate fraction; nBut-F: $n$-butanol fraction; Re-F: residual fraction; MRC-5: human fetal lung fibroblasts; Nd: not determined. Values are means \pm SD of three replicates. 


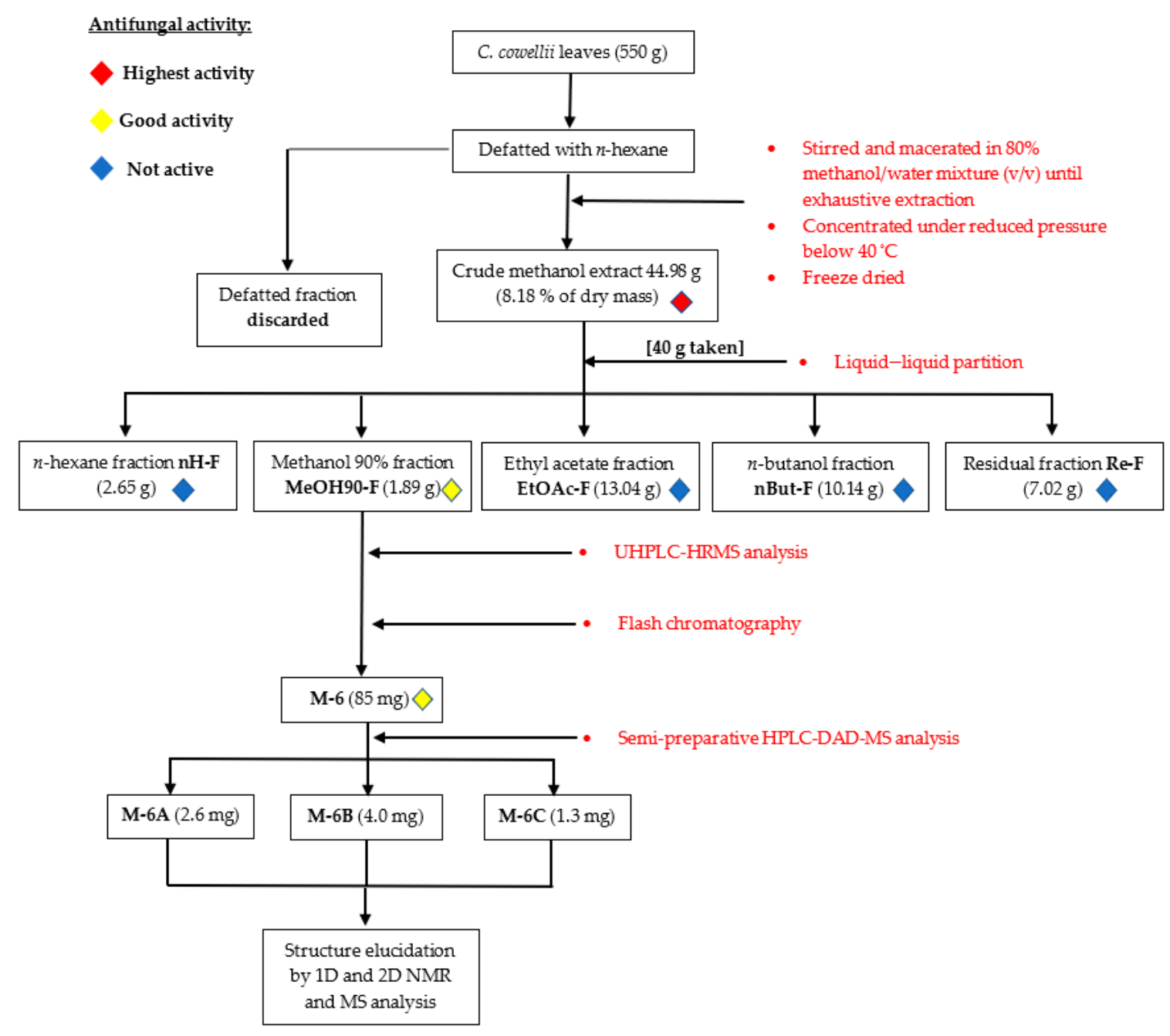

Figure 1. General scheme of the bioassay-guided fractionation performed on the methanolic extract from C. cowellii leaves.

\subsection{UHPLC-HRMS Characterization}

On the basis of the results obtained in the biological assays, the MeOH90-F fraction of C. cowellii was qualitatively analysed for its chemical composition using UHPLC-ESIQTOF-MS in negative ionization mode. The base peak intensities (BPI, peaks 1 to 30 corresponding to Table 1) in negative ionization mode are shown in Figure 2.

The analysis and interpretation of the $\mathrm{MS}^{\mathrm{E}}$ data allowed the identification of 21 phytochemical compounds from a total of 30 peaks (Table 2). The data from formerly identified phytochemicals in the Coccoloba genus and/or the Polygonaceae family were also utilised in the identification when applicable.

The fragment nomenclature for flavonoid glycosides was applied according to $\mathrm{Vu}$ kics and Guttman [9]. The nomenclature used for lignin oligomers and fragments was taken from Morreel et al. [10]. The MS spectra are shown in the Supplementary Material (Figure S1a-o). 


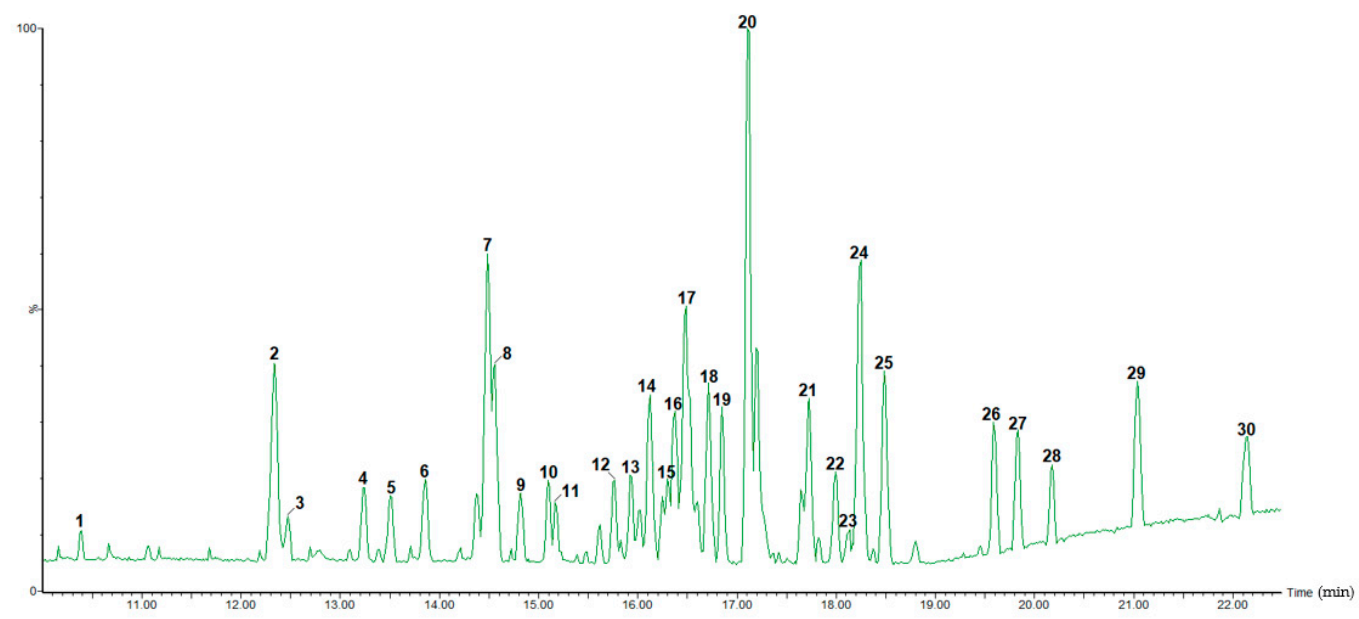

Figure 2. UHPLC-ESI-QTOF-MS base peak intensity (BPI) chromatogram (in negative ion mode) of the MeOH90-F fraction.

Table 2. Chemical composition of the methanol $90 \%$ fraction of the total extract of C. cowellii.

\begin{tabular}{|c|c|c|c|c|c|c|c|}
\hline Peak No. & $\underset{(\mathrm{min})}{\mathrm{Rt}}$ & $\begin{array}{l}{[\mathrm{M}-\mathrm{H}]^{-}} \\
(\mathrm{m} / \mathrm{z})\end{array}$ & $\begin{array}{l}\text { Theoretical } \\
\text { Mass }(\mathrm{m} / \mathrm{z})\end{array}$ & $\begin{array}{l}\text { Accuracy } \\
(\mathrm{ppm})\end{array}$ & $\begin{array}{l}\text { MS/MS } \\
\text { Ions }\end{array}$ & MF & Tentative Identification \\
\hline 1 & 10.39 & 493.0620 & 493.0618 & 0.4 & $\begin{array}{l}317.0281 / \\
315.0105 / \\
287.0563 / \\
178.9872\end{array}$ & $\mathrm{C}_{21} \mathrm{H}_{17} \mathrm{O}_{14}$ & Myricetin-O-glucuronide \\
\hline 2 & 12.33 & 433.0775 & 433.0771 & 0.9 & $\begin{array}{c}301.0344 / \\
300.0273 / \\
271.0247 / \\
255.0294\end{array}$ & $\mathrm{C}_{20} \mathrm{H}_{17} \mathrm{O}_{11}$ & Quercetin-O-pentoside 1 \\
\hline 3 & 12.47 & 433.0763 & 433.0771 & -1.8 & $\begin{array}{c}301.0357 / \\
300.0253 / \\
271.0255 / \\
255.0187\end{array}$ & $\mathrm{C}_{20} \mathrm{H}_{17} \mathrm{O}_{11}$ & Quercetin-O-pentoside 2 \\
\hline 4 & 13.23 & 555.2225 & 555.2230 & -0.9 & $\begin{array}{l}507.2011 / \\
477.1888\end{array}$ & $\mathrm{C}_{30} \mathrm{H}_{35} \mathrm{O}_{10}$ & $\begin{array}{c}\text { Trilignol } \\
\mathrm{G}(8-\mathrm{O}-4) \mathrm{G}(8-5) \mathrm{G}\end{array}$ \\
\hline 5 & 13.50 & 555.2216 & 555.2230 & -2.5 & $\begin{array}{c}507.1984 / \\
477.1816 / \\
341.1288 / \\
329.1320 / \\
195.0650 / \\
165.0273\end{array}$ & $\mathrm{C}_{30} \mathrm{H}_{35} \mathrm{O}_{10}$ & $\begin{array}{c}\text { Trilignol } \\
\mathrm{G}(8-\mathrm{O}-4) \mathrm{G}(8-5) \mathrm{G}\end{array}$ \\
\hline 6 & 13.85 & 312.1228 & 312.1236 & -2.6 & $\begin{array}{l}197.8091 / \\
195.8118 / \\
116.9287\end{array}$ & - & Unknown \\
\hline 7 & 14.49 & 585.2429 & 585.2430 & -0.2 & $\begin{array}{c}537.2122 / \\
507.1984 / \\
371.1458 / \\
359.1454 / \\
195.0658 / \\
165.0374\end{array}$ & $\mathrm{C}_{31} \mathrm{H}_{37} \mathrm{O}_{11}$ & Trilignol G(8-O-4)X(8-8)X \\
\hline 8 & 14.56 & 583.2163 & 583.2179 & -2.7 & $\begin{array}{c}535.1965 / \\
505.1852 / \\
369.1333 / \\
357.1330 / \\
195.0658 / \\
165.0301\end{array}$ & $\mathrm{C}_{31} \mathrm{H}_{35} \mathrm{O}_{11}$ & Trilignol G(8-O-4)S(8-5)G \\
\hline
\end{tabular}


Table 2. Cont.

\begin{tabular}{|c|c|c|c|c|c|c|c|}
\hline Peak No. & $\begin{array}{c}\text { Rt } \\
(\mathrm{min})\end{array}$ & $\begin{array}{c}{[\mathrm{M}-\mathrm{H}]^{-}} \\
(\mathrm{m} / \mathrm{z})\end{array}$ & $\begin{array}{l}\text { Theoretical } \\
\text { Mass }(m / z)\end{array}$ & $\begin{array}{l}\text { Accuracy } \\
(\mathrm{ppm})\end{array}$ & $\begin{array}{l}\text { MS/MS } \\
\text { Ions }\end{array}$ & MF & Tentative Identification \\
\hline 9 & 14.82 & 585.2329 & 585.2336 & -1.2 & $\begin{array}{c}537.2112 / \\
507.1821 / \\
359.1410 / \\
195.0639 / \\
165.0157\end{array}$ & $\mathrm{C}_{31} \mathrm{H}_{37} \mathrm{O}_{11}$ & Trilignol G(8-O-4)X(8-8)X \\
\hline 10 & 15.09 & 585.2331 & 585.2336 & -0.9 & $\begin{array}{c}537.2020 / \\
507.1826 / \\
371.1437 / \\
359.1445 / \\
195.0655 / \\
165.0552\end{array}$ & $\mathrm{C}_{31} \mathrm{H}_{37} \mathrm{O}_{11}$ & Trilignol G(8-O-4)X(8-8)X \\
\hline 11 & 15.17 & 583.2172 & 583.2179 & -1.2 & $\begin{array}{c}369.1325 / \\
357.1325 / \\
195.0656 / \\
165.0551\end{array}$ & $\mathrm{C}_{31} \mathrm{H}_{35} \mathrm{O}_{11}$ & Trilignol G(8-O-4)S(8-5)G \\
\hline & & & & & $\begin{array}{l}565.2036 / \\
489.1883 / \\
477.1877 /\end{array}$ & & \\
\hline 12 & 15.76 & 583.2177 & 583.2179 & -0.3 & $\begin{array}{c}417.1481 / \\
371.1414 / \\
359.1383 / \\
193.0497\end{array}$ & - & Unknown \\
\hline 13 & 16.02 & 583.2177 & 583.2179 & -0.3 & $\begin{array}{l}581.1965 / \\
535.1947 / \\
387.1389 / \\
367.1148 / \\
195.0648 / \\
165.0052\end{array}$ & - & Unknown \\
\hline 14 & 16.12 & 315.0513 & 315.0505 & 2.5 & $\begin{array}{l}300.0270 / \\
271.0238\end{array}$ & $\mathrm{C}_{16} \mathrm{H}_{11} \mathrm{O}_{7}$ & 3-O-Methylquercetin \\
\hline & & & & & $\begin{array}{l}360.0495 / \\
345.0239 / \\
330.0117 /\end{array}$ & & (s) \\
\hline 15 & 16.24 & 375.0704 & 375.0716 & -3.2 & $\begin{array}{c}327.1691 / \\
317.0265 / \\
300.0250 / \\
171.0929\end{array}$ & $\mathrm{C}_{18} \mathrm{H}_{15} \mathrm{O}_{9}$ & $\begin{array}{l}\text { 6-Methoxymyricetin } \\
\text { 3,4'-dimethyl ether }\end{array}$ \\
\hline 16 & 16.37 & 327.2177 & 327.2171 & 1.8 & $\begin{array}{c}285.0412 / \\
256.0378 / \\
229.1443 / \\
211.1334 / \\
171.1033\end{array}$ & - & Unknown \\
\hline 17 & 16.49 & 345.0612 & 345.0610 & 0.6 & $\begin{array}{c}301.0422 \\
300.0278 /\end{array}$ & - & Unknown \\
\hline 18 & 16.71 & 315.0510 & 315.0505 & 1.6 & $\begin{array}{c}271.0252 / \\
255.0304 / \\
243.0296\end{array}$ & $\mathrm{C}_{16} \mathrm{H}_{11} \mathrm{O}_{7}$ & O-Methylquercetin \\
\hline 19 & 16.85 & 809.3019 & 809.3021 & -0.2 & $\begin{array}{c}761.2747 / \\
613.2260 / \\
565.2047 / \\
417.1499 / \\
195.0660\end{array}$ & $\mathrm{C}_{42} \mathrm{H}_{49} \mathrm{O}_{16}$ & $\begin{array}{c}\text { Tetralignol G(8-O-4)G(8- } \\
\text { O-4)S(8-8)S }\end{array}$ \\
\hline 20 & 17.11 & 331.2645 & 331.2637 & 2.4 & 313.2187 & - & Unknown \\
\hline
\end{tabular}


Table 2. Cont.

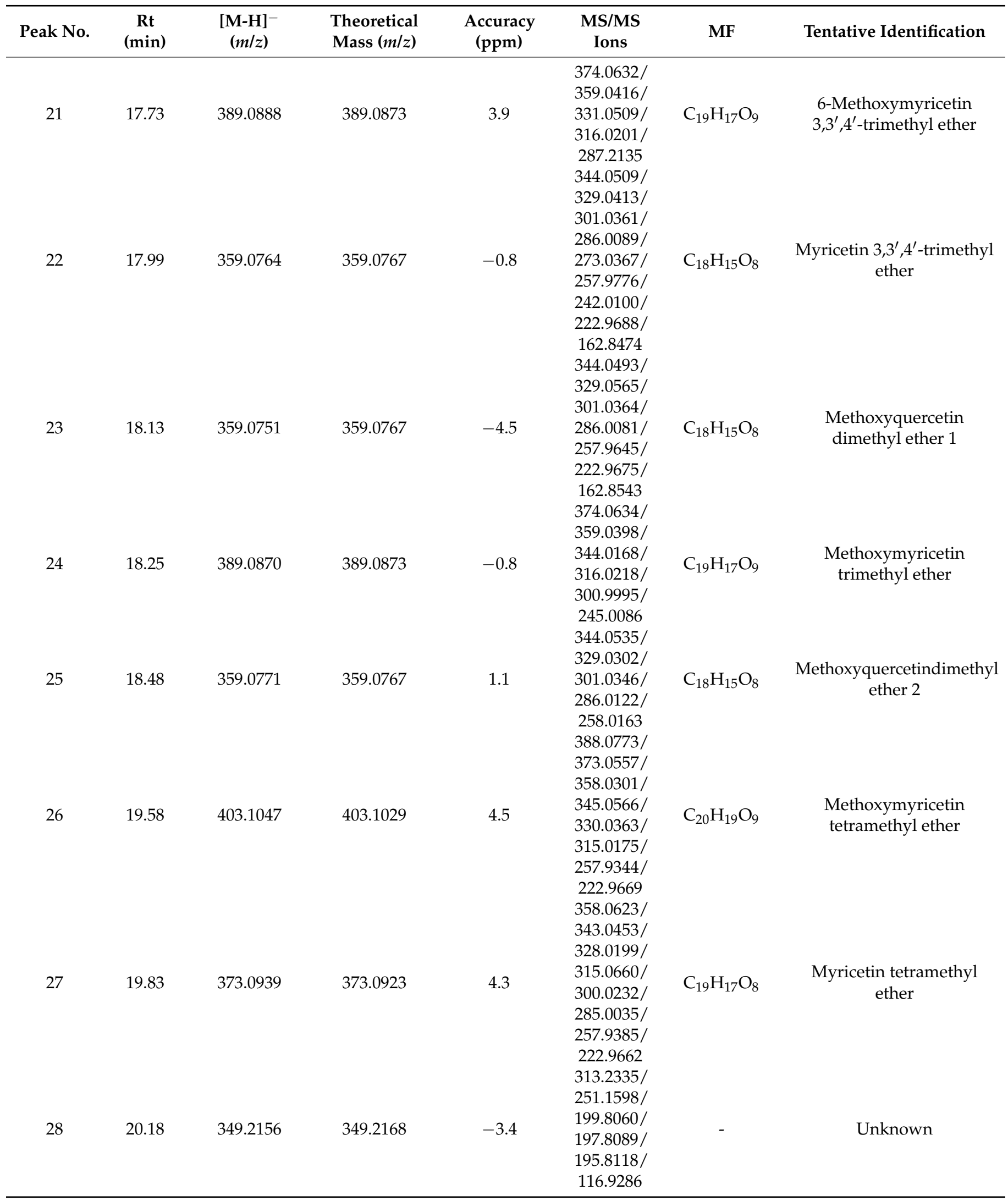


Table 2. Cont.

\begin{tabular}{|c|c|c|c|c|c|c|c|}
\hline Peak No. & $\underset{(\min )}{R t}$ & $\begin{array}{c}{[\mathrm{M}-\mathrm{H}]^{-}} \\
(\mathrm{m} / \mathrm{z})\end{array}$ & $\begin{array}{l}\text { Theoretical } \\
\text { Mass }(m / z)\end{array}$ & $\begin{array}{l}\text { Accuracy } \\
(\mathrm{ppm})\end{array}$ & $\begin{array}{l}\text { MS/MS } \\
\text { Ions }\end{array}$ & MF & Tentative Identification \\
\hline 29 & 21.03 & 721.3658 & 721.3647 & 1.5 & $\begin{array}{c}675.3555 / \\
415.1435 / \\
397.1342 / \\
277.1996 / \\
257.9326 / \\
222.9646\end{array}$ & - & Unknown \\
\hline 30 & 22.15 & 559.3133 & 559.3118 & 2.7 & $\begin{array}{c}567.2234 / \\
505.1054 / \\
320.0494 / \\
277.2092 / \\
257.9327 / \\
222.9659\end{array}$ & - & Unknown \\
\hline
\end{tabular}

Rt: retention time; MF: molecular formula.

\subsubsection{Flavonoid Glycosides/Glucuronides}

MS spectral data from peaks 1-3 matched with those previously reported for the total extract [8]. Peak 1 data fragmentation suggested (see Table 2) the presence of myricetin-Oglucuronide. The main fragment corresponded to the ion at $m / z 317\left[\mathrm{Y}_{0}\right]^{-}$as a consequence of glucuronide loss, followed by a retro Diels-Alder (RDA) fragmentation generating the secondary fragments at $m / z 287\left[\mathrm{Y}_{0}-\mathrm{H}-\mathrm{CO}-\mathrm{H}\right]^{-}$and $m / z 179\left({ }^{1,2} \mathrm{~A}^{-}\right)$. On the other hand, the peak 2 and 3 data implied the presence of a quercetin- $O$-pentoside following similar fragmentation behaviour to compound 1, but with the particularity that both homolytic and heterolytic loss of the sugar could be documented by the presence of ions at $m / z 300\left[\mathrm{Y}_{0}-\mathrm{H}\right]^{-\cdot}$ and $m / z 301\left[\mathrm{Y}_{0}\right]^{-}$, respectively. It was impossible to differentiate between these possible isomers; therefore, they were labelled as quercetin- $O$-pentoside 1 and 2 , respectively.

\subsubsection{Lignin Oligomers}

Peaks 4, 5, 7-11, and 19 all showed similar spectra and fragments. The fragmentation patterns matched the ones reported by Morreel et al. $[10,11]$ for lignin oligomers. Table 3 shows the product ions of 4, 5, and 7-11, identified as trilignols. The fragment ion of $m / z 195$ (present in all the compounds) indicates that the 8-phenolic end ( $\mathrm{A}^{-}$fragment) corresponds to a $\mathrm{G}$ unit (guaiacyl, a unit derived from coniferyl alcohol) [12]. The fragmentation patterns (Figure S2a) were in correspondence with isomers of type $\mathrm{G}(8-\mathrm{O}-4) \mathrm{X}(8-5) \mathrm{X}$ and $\mathrm{G}(8-\mathrm{O}-$ 4) $X(8-8) X$-containing trimers, with $X$ being either an $S$ unit (syringyl, a unit derived from sinapyl alcohol) or the previously mentioned $G$ unit.

Table 3. MS/MS fragmentation patterns of trilignols of the methanol $90 \%$ fraction of the total extract of C. cowellii.

\begin{tabular}{|c|c|c|c|c|c|c|c|}
\hline Ions & Peak 4 & Peak 5 & Peak 7 & Peak 8 & Peak 9 & Peak 10 & Peak 11 \\
\hline$[\mathrm{M}-\mathrm{H}]^{-}$ & $555(18)$ & 555 (49) & $585(41)$ & $583(38)$ & $585(36)$ & $585(58)$ & $583(45)$ \\
\hline$\left[\mathrm{M}-\mathrm{H}-\mathrm{H}_{2} \mathrm{O}\right]^{-}$ & $537(4)$ & $537(12)$ & $567(2)$ & $565(3)$ & $567(2)$ & $567(4)$ & $565(7)$ \\
\hline$\left[\mathrm{M}-\mathrm{H}-\mathrm{H}_{2} \mathrm{O}-\mathrm{CH}_{2} \mathrm{O}\right]^{-}$ & $507(100)$ & $507(90)$ & $537(100)$ & $535(100)$ & $537(100)$ & $537(18)$ & $535(15)$ \\
\hline$\left[\mathrm{M}-\mathrm{H}-\mathrm{H}_{2} \mathrm{O}-\mathrm{CH}_{2} \mathrm{O}-\mathrm{CH}_{2} \mathrm{O}\right]^{-}$ & $477(27)$ & 477 (55) & $507(23)$ & $505(20)$ & $507(13)$ & 507 (12) & $505(10)$ \\
\hline $\mathrm{A}^{-}$ & $195(13)$ & $195(100)$ & 195 (27) & 195 (37) & $195(32)$ & $195(100)$ & $195(100)$ \\
\hline $\mathrm{A}^{-}-\mathrm{CH}_{2} \mathrm{O}$ & $165(13)$ & $165(78)$ & $165(19)$ & $165(31)$ & $165(22)$ & $165(67)$ & $165(70)$ \\
\hline $\mathrm{B}^{-}-\mathrm{H}_{2} \mathrm{O}$ & $341(7)$ & $341(46)$ & $371(24)$ & $369(41)$ & $371(3)$ & $371(66)$ & $369(90)$ \\
\hline $\mathrm{B}^{-}-\mathrm{CH}_{2} \mathrm{O}$ & $329(10)$ & 329 (77) & $359(30)$ & 357 (39) & 359 (50) & 359 (82) & 357 (83) \\
\hline
\end{tabular}


Peak 19 presented a $[\mathrm{M}-\mathrm{H}]^{-}$ion at $m / z 809$ and produced secondary fragmentations at $m / z 761\left[\mathrm{M}-\mathrm{H}-\mathrm{H}_{2} \mathrm{O}-\mathrm{CH}_{2} \mathrm{O}\right]^{-}, m / z 613\left(\mathrm{~B}^{-}\right), m / z 565\left(\mathrm{~B}^{-}-\mathrm{H}_{2} \mathrm{O}-\mathrm{CH}_{2} \mathrm{O}\right.$ ), $m / z 417$ (second $\mathrm{B}^{-}$) and $m / z 195\left(\mathrm{~A}^{-}\right)$. These fragments (Figure $\left.\mathrm{S} 2 \mathrm{~b}\right)$ suggest a tetralignol type $\mathrm{G}(8-\mathrm{O}-$ 4) $\mathrm{G}(8-\mathrm{O}-4) \mathrm{S}(8-8) \mathrm{S}$ structure.

\subsubsection{Methoxyflavonoids}

Peaks 14, 15, 18, and 21-27 all showed one or several losses of $15 \mathrm{Da}$ in their spectra, characteristic of methoxy compounds. The fragmentation patterns can be partially matched to the ones reported by Zhang et al. [13]. Table 4 shows the product ions of peaks 14, 15, 18 , and 21-27, and the different losses were characteristic of polymethoxyflavonoids with at least three methoxy groups, except for peaks 14 and 18, which only contained one methoxy group.

Table 4. MS/MS fragmentation patterns of methoxyflavonoids of the methanol $90 \%$ fraction of the total extract of C. cowellii.

\begin{tabular}{|c|c|c|c|c|c|c|c|c|c|c|}
\hline Ions & Peak 14 & Peak 15 & Peak 18 & Peak 21 & Peak 22 & Peak 23 & Peak 24 & Peak 25 & Peak 26 & Peak 27 \\
\hline$[\mathrm{M}-\mathrm{H}]^{-}$ & $315(15)$ & $375(12)$ & $315(25)$ & $389(19)$ & $359(39)$ & $359(19)$ & $389(12)$ & $359(12)$ & $403(19)$ & $373(11)$ \\
\hline$\left[\mathrm{M}-\mathrm{H}-\mathrm{CH}_{3} .\right]^{-}$ & $\begin{array}{c}300 \\
(100)\end{array}$ & $360(36)$ & $300(66)$ & $374(44)$ & $344(65)$ & $344(40)$ & $374(22)$ & $344(7)$ & $388(54)$ & $358(11)$ \\
\hline$\left[\mathrm{M}-\mathrm{H}-2 \mathrm{CH}_{3} .\right]^{-}$ & - & $\begin{array}{c}345 \\
(100)\end{array}$ & - & $\begin{array}{c}359 \\
(100)\end{array}$ & $\begin{array}{c}329 \\
(100)\end{array}$ & $329(100)$ & $\begin{array}{c}359 \\
(100)\end{array}$ & $\begin{array}{c}329 \\
(100)\end{array}$ & $\begin{array}{c}373 \\
(100)\end{array}$ & $\begin{array}{c}343 \\
(100)\end{array}$ \\
\hline$\left[\mathrm{M}-\mathrm{H}-3 \mathrm{CH}_{3} .\right]^{-}$ & - & $330(17)$ & - & $344(13)$ & $314(15)$ & $314(16)$ & $344(36)$ & $314(7)$ & $358(34)$ & $328(12)$ \\
\hline$\left[\mathrm{M}-\mathrm{H}-2 \mathrm{CH}_{3} .-\mathrm{CO}\right]^{-}$ & - & $317(15)$ & - & $331(38)$ & $301(54)$ & $301(49)$ & $331(7)$ & $301(16)$ & $345(33)$ & $315(10)$ \\
\hline$\left[\mathrm{M}-\mathrm{H}-2 \mathrm{CH}_{3} \cdot-\mathrm{CO}-\mathrm{CH}_{3} \cdot\right]^{-}$ & - & - & - & $316(32)$ & $286(42)$ & 286 (43) & 316 (44) & $286(19)$ & $330(69)$ & 300 (13) \\
\hline$\left[\mathrm{M}-\mathrm{H}-2 \mathrm{CH}_{3} \cdot-\mathrm{CO}-2 \mathrm{CH}_{3} .\right]^{-}$ & - & - & - & $301(17)$ & - & - & $301(16)$ & - & $315(34)$ & $285(7)$ \\
\hline$\left[\mathrm{M}-\mathrm{H}-2 \mathrm{CH}_{3} \cdot-\mathrm{H}_{2} \mathrm{O}\right]^{-}$ & - & $327(24)$ & - & $341(17)$ & - & - & - & - & - & - \\
\hline$\left[\mathrm{M}-\mathrm{H}-\mathrm{CH}_{3} \cdot-\mathrm{HCO} .\right]^{-}$ & $271(12)$ & - & $\begin{array}{c}271 \\
(100)\end{array}$ & - & - & - & - & - & - & - \\
\hline Others & & $\begin{array}{l}300(22) \\
171(24)\end{array}$ & $\begin{array}{l}255(42) \\
243(20)\end{array}$ & $\begin{array}{l}287(62) \\
245(15)\end{array}$ & $\begin{array}{l}273(46) \\
258(62)\end{array}$ & $\begin{array}{l}258(48) \\
223(22) \\
163(18)\end{array}$ & $245(12)$ & $258(14)$ & $258(37)$ & \\
\hline
\end{tabular}

The relative intensity of the product ions compared with the base peak is given in parentheses.

Flavonoid glycosides and glucuronides with quercetin and myricetin aglycon moiety have already been reported in relatively high concentrations in the total extract of $C$. cowellii leaves [8] and in other species of the genus [14]. In fact, compounds 1-3 from this study matched the ones previously identified in the total extract [8]. The other compounds identified in the methanol $90 \%$ fraction were reported in this species for the first time.

Lignans and lignanoids are not commonly found in members of the Polygonaceae family and we could not find any report of this type of compound for the Coccoloba genus. Lignan glycosides have been isolated from the aerial parts of Polygonum bellardii [15]. Other lignin oligomers have been reported in Polygonum perfoliatum [16,17], Polygonum aviculare [18], Rheum austral [19], Atraphaxis frutescens [20], and Polygonumcapitatum [21]. On the other hand, methoxyflavonoids and their glycosides only occur in a few species of the Polygonaceae family, and we could not find any report of this type of compound in the Coccoloba genus. 5,8,3', 4',5'-Pentahydroxy-3,7-dimethoxyflavone and 3-O-methylquercetin were isolated from an ethyl acetate extract and fractions of Chorizanthe diffusa [22]. Some methoxymyricetin derivatives, including 3-O-methylmyricetin-3'-O- $\beta$-D-xylopyranoside and 3-O-methylmyricetin, were isolated from the roots of Pteroxygonum giraldii [23]. Furthermore, the chemical investigation of the aerial parts of Atraphaxis frutescens resulted in the isolation of five 7-methoxyflavonols [20]. Isorhamnetin and 3,7-dihydroxy-5,6dimethoxyflavone were among the compounds isolated from the dichloromethane extract of Polygonum hydropiper [24], and myricetin 3,7,3', $4^{\prime}$-tetramethyl ether has been isolated from Polygonum viscosum [25] and Polygonum perfoliatum [17].

The harsh growing conditions of $C$. cowellii can be associated with the presence of compounds unique to this species. This plant, strictly endemic to the savannas of north Camagüey, Cuba, only grows on serpentine soils and is subjected to almost constant drought and high levels of solar radiation (Figure S3). Its leaves are quite hard, with a 
lignified cuticula to prevent water loss. Therefore, these relatively rare compounds may be synthesised as a way to adapt to such severe adverse conditions [26].

These results portray a complex panorama: while the highly active total extract is rich in quercetin and myricetin glucosides/glucuronides and proanthocyanidins, its only active fraction is mainly comprised of lignans and methyl and methoxy derivatives of quercetin and myricetin. Only the aforementioned compounds 1-3 were common between both active tested extracts. In addition, and as can be seen in Figure 1, the lowest yield of extractable substances was obtained for the methanol $90 \%$ fraction, and therefore, active compounds must be present at very low concentrations in the crude extract. In fact, this could be an explanation for why such lignanoids and methoxyflavonoids were not detected during the study of the total extract. Despite these unfavourable conditions, biofractionation was pursued, aided by flash chromatography.

This second fractionation rendered 24 subfractions, which were all evaluated for their antifungal activity. Only one subfraction, M-6, showed some activity against $C$. neoformans and C. glabrata (Table 5). Therefore, this subfraction was selected for the isolation and characterization of its components through a semi-preparative HPLC-DAD-MS.

Table 5. In vitro antifungal and cytotoxic activity of subfraction M-6 and the binary mixtures M-6A, M-6B, and M-6C from C. cowellii leaves.

\begin{tabular}{cccccccc}
\hline Test Sample & Cytotoxicity $\left(\mathrm{CC}_{\mathbf{5 0}} \boldsymbol{\mu \mathrm { g } / \mathrm { mL } )}\right.$ & \multicolumn{5}{c}{ Antifungal Screening $\left(\mathbf{I C} \mathbf{5 0}_{\mathbf{5 0}} \mathbf{\mu g} \mathbf{m L}\right)$} \\
\hline & MRC-5 & A. fumigatus & C. neoformans & C. albicans & C. parapsilosis & C. glabrata & C. tropicalis \\
\hline M-6 & $>64.0$ & $>64.0$ & $50.3 \pm 9.2$ & $>64.0$ & $>64.0$ & $9.5 \pm 1.1$ & $>64.0$ \\
\hline M-6A & $>64.0$ & $>64.0$ & $>64.0$ & $>64.0$ & $>64.0$ & $7.9 \pm 1.3$ & $>64.0$ \\
\hline M-6B & $>64.0$ & $>64.0$ & $59.5 \pm 6.4$ & $>64.0$ & $>64.0$ & $9.1 \pm 1.8$ & $>64.0$ \\
\hline M-6C & $>32.0$ & $>32.0$ & $8.3 \pm 0.0$ & $>32.0$ & $>32.0$ & $3.8 \pm 0.0$ & $>32.0$ \\
\hline Miconazole & $19.8 \pm 0.7$ & $3.7 \pm 0.5$ & $0.2 \pm 0.0$ & $3.4 \pm 0.2$ & $1.1 \pm 0.1$ & $0.2 \pm 0.0$ & $3.6 \pm 1.0$ \\
\hline
\end{tabular}

M-6: subfraction of the flash chromatography of MeOH90-F; M-6A: compound I and minor impurity; M-6B: mixture of compounds II and III; M-6C: mixture of compounds IV and V. MRC-5: human fetal lung fibroblasts. Values are means \pm SD of three replicates.

\subsection{Isolated Compounds}

The semi-preparative HPLC-DAD-MS procedure rendered three main isolates (M-6A, $\mathrm{M}-6 \mathrm{~B}$, and M-6C) with yields of 2.6, 4.0, and $1.3 \mathrm{mg}$, respectively (Figure 1). The analysis of the ${ }^{1} \mathrm{H}$ NMR spectra revealed that M-6A, M-6B, and M-6C were mixtures of two compounds in different ratios (Figure $3 \mathrm{a}$ ). The low yields obtained did not allow further purification. Nevertheless, it was possible to determine the structures of both the major and minor compounds, except for the minor compound of M-6A. Employing the results obtained from SMART 2.1 (Tables S1-S5, Supplementary Information) and the molecular weight derived from the $m / z$ value of the $[\mathrm{M}-\mathrm{H}]^{-}$peaks, a preliminary structure was drawn.

M-6A was identified as a mixture of quercetin (major, compound I) and an unidentified impurity (minor) (amorphous yellow powder, $2.6 \mathrm{mg}$ ). The NMR data (Figure S4) were similar to those previously reported in the literature for quercetin [27].

$\mathrm{M}-6 \mathrm{~B}$ was identified as a mixture of 3-O-methylquercetin (major, compound II) and 6-methoxymyricetin 3,4'-dimethyl ether (minor, compound III) (amorphous yellow powder, $4.0 \mathrm{mg}$ ). The position of substituents was corroborated through ${ }^{2} J_{\mathrm{H}-\mathrm{C}}$ and ${ }^{3} J_{\mathrm{H}-\mathrm{C}}$ HMBC correlations (Figure 3b). NMR data (Figure S5) coincided with the data reported in the literature for 3-O-methylquercetin [28] and 6-methoxy-3-O-methylmearnsetin (6methoxymyricetin 3,4'-dimethyl ether) [29]. Both compounds corresponded with peaks 14 and 15 proposed in the UHPLC-HRMS analysis. 
<smiles>[R]Oc1c([R20])cc(-c2oc3cc(O)c([R])c(O)c3c(=O)c2O)cc1O</smiles>

$\begin{array}{cc}\text { Compound } & \mathbf{R}_{1} \\ \text { I } & -\mathrm{H} \\ \text { II } & -\mathrm{H} \\ \text { III } & -\mathrm{OH} \\ \text { IV } & -\mathrm{OCH}_{3} \\ \text { V } & -\mathrm{OCH}_{3}\end{array}$

$\begin{array}{cc}\mathbf{R}_{2} & \mathbf{R} 3 \\ -\mathrm{H} & -\mathrm{H} \\ -\mathrm{H} & -\mathrm{CH}_{3} \\ -\mathrm{CH}_{3} & -\mathrm{CH}_{3} \\ -\mathrm{CH}_{3} & -\mathrm{CH}_{3} \\ -\mathrm{CH}_{3} & -\mathrm{CH}_{3}\end{array}$

$\mathbf{R}_{4}$

$-\mathrm{H}$

$-\mathrm{H}$

$-\mathrm{OCH}_{3}$

$-\mathrm{OCH}_{3}$

$-\mathrm{H}$

(a)

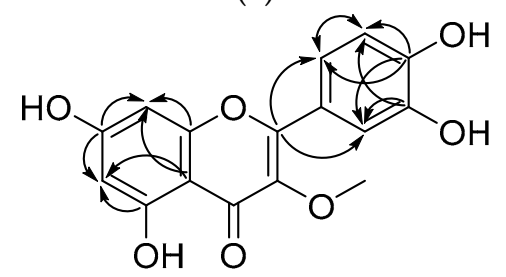

(b)

Figure 3. (a) Structures of compounds isolated from leaves of C. cowellii. (b) Correlations ${ }^{2} J_{\mathrm{H}-\mathrm{C}}$ and ${ }^{3} J_{\mathrm{H}-\mathrm{C}}$ observed in the HMBC spectra of compound II.

M-6C was identified as a mixture of 6-methoxymyricetin 3,3', $4^{\prime}$-trimethyl ether (major, compound IV), and myricetin $3,3^{\prime}, 4^{\prime}$-trimethyl ether (minor, compound V) (amorphous yellow powder, $1.3 \mathrm{mg}$ ). The NMR spectral data (Figure S6) were in agreement with the assignments reported in the literature for 5,7,3'-trihydroxy-3,6, $4^{\prime}, 5^{\prime}$-tetramethoxyflavone (6methoxymyricetin 3,3', $4^{\prime}$-trimethyl ether) [25] and for myricetin 3,3', $4^{\prime}$-trimethyl ether [30]. Both compounds corresponded with peaks 21 and 22 proposed in the UHPLC-HRMS analysis.

For the structure elucidation, NMR data of compounds with a similar chemical backbone were consulted for comparison [31-33].

Table 5 shows the activities of subfraction M- 6 and the mixtures of compounds defined as M-6A, M-6B, and M-6C. As can be seen, the antifungal activity of the binary mixture M-6C against C. glabrata and C. neoformans was approximately the same as the activity of the methanol $90 \%$ fraction, but the activity remained lower than that of the total extract. Furthermore, it was noted that the M-6 fraction and the three mixtures of compounds were active against $C$. glabrata specifically. The increasing resistance of this Candida species against azole compound [4] and echinocandins [34] necessitate the search for novel compounds that can be used to treat infections caused by this fungus.

Methoxyflavonoids (specifically, derivatives of the flavonols quercetin and myricetin) seem to be responsible for the observed activity. Antifungal activity has previously been reported for these types of compounds [35,36]. The analysis of Limonium caspium (Plumbaginaceae) showed that the compound 5-methylmyricetin exhibited good antifungal activity against $C$. glabrata, with an $\mathrm{IC}_{50}$ value of $6.79 \mu \mathrm{g} / \mathrm{mL}$ [37]. From Combretum zeyheri (Combretaceae), the compound 5-hydroxy-7,4'-dimethoxyflavone was found to be active against C. albicans using the broth dilution method. These substances showed synergistic activity when combined with miconazole, completely inhibiting $C$. albicans growth after only $4 \mathrm{~h}$ of incubation [38]. The study of the plant Kaempferia parviflora (Zingiberaceae) allowed the identification of 3,5,7,4'-tetramethoxyflavone and 5,7,4'-trimethoxyflavone as 
acceptable antifungal agents against $C$. albicans, with respective $\mathrm{IC}_{50}$ values of 39.71 and $17.63 \mu \mathrm{g} / \mathrm{mL}[39]$.

\subsection{Antibiofilm Screening Assay}

Plant extracts and/or their isolated compounds can act as antimicrobials via different mechanisms. Biofilm disruption is one of the most explored, and the active extracts/fractions/compounds were tested for this mode of action. The biofilm screening assay was realised by employing the C. albicans SC5314 strain [40]. The formation of fungal biofilms decreased overall susceptibility from both host defences and antimicrobial therapies [41]. Natural products have been reported to demonstrate antibiofilm activity, which is relevant because developing resistance to these kinds of molecules is rare [42]. The results showed (Table 6) that only the total extract showed low activity against the C. albicans biofilms, while the rest of the samples showed no effect at the tested concentrations ( 0.25 to $64 \mu \mathrm{g} / \mathrm{mL}$ to all the samples except for M-6C due to the low amount).

Table 6. In vitro antibiofilm activity of the total extract and fractions from C. cowellii leaves.

\begin{tabular}{cc}
\hline Test Sample & Antibiofilm Screening $\left(\mathbf{I C} \mathbf{5 0}_{\mathbf{~} \mathbf{g} / \mathbf{m L})}\right.$ \\
\hline TE & Candida albicans SC5314 \\
MeOH90-F & $49.73 \pm 2.1$ \\
M-6 & $>64.00$ \\
M-6A & $>64.00$ \\
M-6B & $>64.00$ \\
M-6C & $>64.00$ \\
Miconazole & $>32.00$ \\
\hline
\end{tabular}

TE: total extract; MeOH90-F: methanol 90\% fraction of TE: M-6: subfraction of the flash chromatography of MeOH90-F; M-6A: compound I and minor impurity; M-6B: mixture of compounds II and III; M-6C: mixture of compounds IV and V. Values are means \pm SD of three replicates.

This assay indicated that the antifungal activity of the total extract of C. cowellii on Candida species is mainly targeted to planktonic cells and has rather low activity against biofilm colonies, at least in the conditions established in these experiments. The mechanism(s) of action of the total extract and active fractions could thus be related to inducing the death of free-living cells and not the disruption of cell-to-cell communication and biofilm association.

\section{Discussion}

The bioassay-guided fractionation performed on C. cowellii leaves led to the isolation and tentative identification of at least 21 new compounds in this species; nevertheless, the isolation of the compounds responsible for high antifungal activity shown by the total extract was not successful. Unfortunately, this is not an uncommon situation. Bioassayguided fractionation of plant extracts is not always effective. This procedure can lead to failures in the isolation of active compounds and losses of activity [43]. The probable degradation of the compounds during the purification process, the difficulty related to isolating bioactive compounds present in low concentrations, and/or the loss of other substances responsible for potential synergistic effects are some of the causes referred to in the literature [44]. In any case, the higher and broader activity of the total extract of C. cowellii compared with the fractions and mixtures of compounds can be associated with any of these aforementioned events.

According to the previous analysis, flavonoid glycosides or glucuronides as well as proanthocyanidins are the main compounds of the total extract of C. cowellii leaves [8]. These compounds have a broad spectrum of biological activities, including antifungal activity $[45,46]$. This mixture of different kinds of polyphenols can contribute to the overall antifungal activity, considering that the different groups can have different underlying mechanisms of action [35]. Proanthocyanidins have shown synergic effects with vari- 
ous commercial antifungal agents. Catechin and epigallocatechin gallate have shown synergism with fluconazole. These compounds induce the activation of the phospholipid phosphatidylserine, which inhibits fatty acid synthase [47], supporting in this way the action mechanism of fluconazole. In a preclinical study of disseminated candidiasis, epigallocatechin-O-gallate administered with amphotericin B showed a synergistic interaction against $C$. albicans. The results of the assay showed that epigallocatechin-O-gallate exclusively inhibits the hyphal formation and ergosterol synthesis of the fungi [48]. The synergic effect of these main compounds, together with the effect of the methoxyflavonoids (see Table 3), is a plausible explanation for the high antifungal activity identified in the total extract of $C$. cowellii leaves. In any case, the extract is a promising candidate for the treatment of fungal diseases, either alone or mixed with commercial antifungals as a way to increase their effectiveness and/or decrease the required doses. Confirmatory assays will be necessary to corroborate these hypotheses.

\section{Materials and Methods}

\subsection{Chemicals and Plant Material}

Acros Organics (Geel, Belgium) and Fisher Scientific (Leicestershire, UK) were the companies from which all analytical grade solvents, such as $n$-hexane, chloroform, dichloromethane, ethyl acetate, isopropyl alcohol, $n$-butanol, methanol, and dimethyl sulfoxide (DMSO), were purchased. HPLC solvents, such as methanol and acetonitrile, were purchased from Fisher Scientific, while UPLC-grade solvents, such as acetonitrile and formic acid, were purchased from Biosolve (Valkenswaard, the Netherlands). Finally, methanol- $d 4$ ( $\geq 99.8 \%$ D) was obtained from Sigma-Aldrich (St. Louis, MO, USA); Milli-Q quality water was dispensed using a Milli-Q system from Millipore (Bedford, MA, USA) and subsequent membrane filtration at $0.22 \mu \mathrm{m}$ was performed before use. Coccoloba cowellii leaves were collected near Albaisa in the municipality of Camagüey, Cuba (Lat. 21.43615, Long. - 77.83253), and were taxonomically identified by the curator of the herbarium "Julián AcuñaGalé" of the University of Camagüey (HIPC, http://sweetgum.nybg.org/science/ih/herbarium-details/?irn=124935 (accessed on 20 August 2021)), where a sample specimen (number 12057) was deposited.

\subsection{Leaf Extraction and Bioassay-Guided Fractionation}

The plant material was processed, and the total extract was obtained as previously described [8]. The total extract $(40.00 \mathrm{~g})$ was dissolved in acidic $(\mathrm{pH}<3)$ methanol 50\% and partitioned with dichloromethane. The dichloromethane residue was concentrated and partitioned between $n$-hexane and methanol $90 \%$. Next, the extract was basified with concentrated ammonia until it reached a $\mathrm{pH}>9$, and partitioning with ethyl acetate and then $n$-butanol was performed. The yield of all the fractions was $2.65 \mathrm{~g}$ for the $n$-hexane fraction (nH-F), $1.89 \mathrm{~g}$ for the methanol 90\% fraction (MeOH90-F), $13.04 \mathrm{~g}$ for the ethyl acetate fraction (EtOAc-F), $10.14 \mathrm{~g}$ for the $n$-butanol fraction (nBut-F), and $7.02 \mathrm{~g}$ for the residual fraction (Re-F). The total yield of the fractionation was $86.9 \%$. nH-F, MeOH90-F, EtOAc-F, and nBut-F were concentrated under reduced pressure at $40{ }^{\circ} \mathrm{C}$ and then stored at $-20{ }^{\circ} \mathrm{C}$ until further use.

\subsection{Antifungal Assay}

The microdilution method with resazurin (redox indicator) in sterile 96-well microplates was the assay used to determine antifungal activity. This was performed according to the protocols of the Laboratory of Microbiology, Parasitology, and Hygiene (LMPH) as previously reported $[8,49]$. Miconazole was used as a positive control.

\section{Microorganisms and Dilutions}

The microorganisms used in the study were obtained from the culture collection of the Laboratory of Microbiology, Parasitology, and Hygiene (LMPH of the University of Antwerp). The strains of Candida albicans ATCC B59630 (azole-resistant), Candida glabrata ATCC B63155, Candida parapsilosis ATCC B66126, Candida tropicalis ATCC CDC44 as well as 
Aspergillus fumigatus ATCC B42928 and Cryptococcus neoformans ATCC B66663 were used for in vitro screening of antifungal activity. The LMPH protocols established for the culture of the microorganisms and the dilutions of the samples were followed, as performed and reported in previous publications $[8,49]$. Tested sample concentrations ranged from 0.25 to $128 \mu \mathrm{g} / \mathrm{mL}$.

\subsection{Antibiofilm Screening Assay}

The antibiofilm assay was performed following the LMPH protocols previously reported [50]. A Candida albicans SC5314 overnight culture, grown in RPMI, was diluted to an optical density (OD) of 0.04-0.05 in RPMI medium, and $95 \mu \mathrm{L}$ of this suspension was added to a 96-well plate. Then, $5 \mu \mathrm{L}$ samples and control (miconazole) were added (in a final concentration range from 0.25 to $128 \mu \mathrm{g} / \mathrm{mL}$ ). The plate was wrapped in parafilm and placed in a styropor box, a cup of MilliQ water was added, and the box was placed in a shaking incubator at $37^{\circ} \mathrm{C}$ and $25 \mathrm{rpm}$. After $24 \mathrm{~h}$ of incubation, the medium was carefully removed with a vacuum pump, avoiding contact of pipette tips with the biofilms. Finally, the biofilms were washed and quantified by adding $150 \mu \mathrm{L}$ of resazurin solution $(1 / 10$ in PBS) to each well. The plate was wrapped in aluminium foil and incubated in the dark at $37^{\circ} \mathrm{C}$ for $1 \mathrm{~h}$. The fluorescence was measured with a microplate reader (TECAN GENios, Männedorf, Switzerland) at a $\lambda_{\mathrm{ex}}$ of $550 \mathrm{~nm}$ and a $\lambda_{\mathrm{em}}$ of $590 \mathrm{~nm}$.

\subsection{Cytotoxicity Assay}

Human foetal lung fibroblasts (MRC-5 SV2 cells) were purchased from the ATCC (American Type Culture Collection). For their culture and assay, the protocols of the Laboratory of Microbiology, Parasitology, and Hygiene (LMPH) were followed, as reported in previous publications $[8,49]$. The $50 \%$ cytotoxic concentration $\left(\mathrm{CC}_{50}\right)$, resulting from the $\%$ reduction of cell growth/viability compared to control wells, is reported. Tamoxifen was used as a reference drug.

\subsection{UHPLC-HRMS Characterization}

The UHPLC-ESI-QTOF-MS analysis of $C$. cowellii extract was carried out as previously reported [8]. $\mathrm{H}_{2} \mathrm{O}+0.1 \% \mathrm{FA}$ (A) and $\mathrm{ACN}+0.1 \% \mathrm{FA}$ (B) were used as mobile phase, and a flow gradient of (min/B\%): 0.0/2.0, 1.0/2.0, 14.0/26.0, 24.0/65.0, 26.0/100.0, 29.0/100.0, $31.0 / 2.0$, and $36.0 / 2.0$ was used. $\mathrm{MS}^{\mathrm{E}}$ in negative ionization mode (two analyses per mode), was recorded. A collision energy ramp from 10 to $30 \mathrm{~V}$ was applied to obtain additional structural information. Leucine-encephalin was used as a blocking mass. UV detection was performed at a wavelength equivalent to $360 \mathrm{~nm}$.

\section{Data Processing}

The UHPLC-ESI-QTOF-MS raw data were analysed using MassLynx 4.1 Copyright (C) 2014 Waters Inc. (Waters, Milford, MA, USA). For identification, the following public databases were consulted: PubChem (https:/ / pubchem.ncbi.nlm.nih.gov / (accessed on 20 August 2021)), ChemSpider (https:/ / www.chemspider.com/ (accessed on 20 August 2021)), MassBank of North America (MoNA) (http://mona.fiehnlab.ucdavis.edu/ (accessed on 20 August 2021)), and NIST Mass Spectrometry Data Center (http:/ / chemdata. nist.gov/ (accessed on 20 August 2021)).

\subsection{Isolation of Constituents from Active Fractions}

In the fractionation of the MeOH90-F fraction (1.7 g), selected as the most active, flash chromatography was applied on a GraceResolv $80 \mathrm{~g}$ silica column using a RevelerisiES system (Columbia, MD, USA). A gradient program consisting of dichloromethane (A), ethyl acetate (B), and methanol (C) as mobile phases and a flow rate of $40 \mathrm{~mL} / \mathrm{min}$ were used (Figure S7). These solvents were applied as follows: 0 to $6 \mathrm{~min} 100 \% \mathrm{~A}, 0 \% \mathrm{~B}$, and $0 \% \mathrm{C} ; 6$ to $40 \mathrm{~min}$ linear changing until $0 \% \mathrm{~A}$ and $100 \% \mathrm{~B} ; 40$ to $45 \mathrm{~min} 0 \% \mathrm{~A}, 100 \% \mathrm{~B}$, and $0 \%$ C; 45 to 81 min linear changing until $0 \%$ B and 100\% C. An evaporative light 
scattering detector (ELSD) and UV absorption at 254 and $366 \mathrm{~nm}$ were used as the detection methods. According to their TLC profile, all collected subfractions were pooled for a total of 24 subfractions (M-1 to M-24).

On the basis of its chromatographic profile, fraction size, and biological activity, subfraction M-6 (85 mg) was selected for further purification by semi-preparative HPLCDAD-MS (Waters, Milford, MA, USA). A C18 Luna (250 mm $\times 10.0 \mathrm{~mm}$, particle size $5 \mu \mathrm{m}$ ) from Phenomenex (Utrecht, The Netherlands) was used as a column. As in previous experiments, $\mathrm{H}_{2} \mathrm{O} / 0.1 \%$ formic acid (A) and acetonitrile (B) were used as mobile phases; consistent linear gradients were applied as follows: 0-5 min 25\% B, 38 min 45\% B, 40-45 $\min 95 \% \mathrm{~B}, 50-60 \mathrm{~min} 25 \% \mathrm{~B}$, and the flow rate was $3.0 \mathrm{~mL} / \mathrm{min}$.

Mass spectra in negative ESI mode, MS scan range: $m / z 150$ to $750 ; \mathrm{V}_{\text {capillary }} 3.00 \mathrm{kV}$, $\mathrm{V}_{\text {cone }} 50 \mathrm{~V}, \mathrm{~V}_{\text {extractor }} 3 \mathrm{~V}$, VRF Lens $0.2 \mathrm{~V}, \mathrm{~T}_{\text {source }} 135^{\circ} \mathrm{C}, \mathrm{T}_{\text {desolvation }} 400{ }^{\circ} \mathrm{C}$, desolvation gas flow $750 \mathrm{~L} / \mathrm{h}$, and cone gas flow $0 \mathrm{~L} / \mathrm{h}$ were obtained, along with the DAD spectrum, which was recorded in the range between 200 and $450 \mathrm{~nm}$. The $m / z$ value and the UV spectrum conditioned the selection of the peaks of interest. In turn, $m / z$ values that exceeded the set threshold served as a trigger for eluate collection. Three compounds were provisionally isolated: M-6A (2.6 mg), M-6B (4.0 mg), and M-6C (1.3 mg).

\subsection{Structure Elucidation}

A Bruker DRX-400 instrument (Rheinstetten, Germany), equipped with either a $3 \mathrm{~mm}$ broadband inverse (BBI) probe or a $5 \mathrm{~mm}$ dual ${ }^{1} \mathrm{H} /{ }^{13} \mathrm{C}$ probe was used to record the NMR spectra, using standard Bruker pulse sequences. $1 \mathrm{D}^{1} \mathrm{H}(400 \mathrm{MHz})$ and ${ }^{13} \mathrm{C}(100 \mathrm{MHz})$, as well as DEPT-135, DEPT-90, and 2D NMR (COSY, HSQC, and HMBC) experiments, were used to characterize the isolated compounds. Bruker TopSpin $\AA_{\text {software version }}$ 4.0.8 for Windows (Billerica, MA, USA) was selected for NMR data processing. In turn, the prediction of chemical structures from NMR data was performed using the NMRbased machine learning tool "Small Molecule Accurate Recognition Technology" (SMART 2.1, available at https://smart.ucsd.edu/classic (accessed on 20 August 2021)). These proposed results were contrasted with those obtained from mass spectra derived from the semi-preparative HPLC-DAD-MS system.

Quercetin (compound I, yellow powder (2.6 mg)): ${ }^{1} \mathrm{H}$ NMR (400 MHz, MeOD): $\delta 6.20$ (s, 1H, H-6); 6.40 (s, 1H, H-8); $6.90\left(\mathrm{~d}, J=8.4 \mathrm{~Hz}, 1 \mathrm{H}, \mathrm{H}-5^{\prime}\right) ; 7.65(\mathrm{dd}, J=1.7,8.4 \mathrm{~Hz}, 1 \mathrm{H}$, H-6' $) ; 7.754 .86\left(\mathrm{~d}, J=1.7 \mathrm{~Hz}, 1 \mathrm{H}, \mathrm{H}-2^{\prime}\right) .{ }^{13} \mathrm{C} \mathrm{NMR}$ (100 MHz, MeOD): $\delta 93.8$ (C-8), 98.8 (C-6), 104.0 (C-10), $115.7\left(\mathrm{C}-2^{\prime}\right), 115.8\left(\mathrm{C}-5^{\prime}\right), 121.3\left(\mathrm{C}-6^{\prime}\right), 123.7\left(\mathrm{C}-1^{\prime}\right), 145.8\left(\mathrm{C}-3^{\prime}\right), 147.5$ (C-2), $148.3\left({\mathrm{C}-4^{\prime}}^{\prime}\right), 157.8$ (C-9), 162.0 (C-5), 165.1 (C-7). ESI-MS (negative mode): $\mathrm{m} / z 301$ $[\mathrm{M}-\mathrm{H}]^{-}\left(\mathrm{C}_{15} \mathrm{H}_{9} \mathrm{O}_{7}\right)$.

3-O-Methylquercetin (compound II, yellow powder $(4.0 \mathrm{mg})$ ): ${ }^{1} \mathrm{H} \mathrm{NMR}(400 \mathrm{MHz}$, MeOD): $\delta 3.79$ (s, 3H, 3-OCH $)$; 6.22 (s, 1H, H-6); 6.41 (s, 1H, H-8); 6.92 (d, J = 8.5 Hz, 1H, $\left.\mathrm{H}-5^{\prime}\right) ; 7.54\left(\mathrm{dd}, J=1.8,8.5 \mathrm{~Hz}, 1 \mathrm{H}, \mathrm{H}-6^{\prime}\right) ; 7.64\left(\mathrm{~d}, J=1.8 \mathrm{~Hz}, 1 \mathrm{H}, \mathrm{H}-2^{\prime}\right) .{ }^{13} \mathrm{C} \mathrm{NMR}(100 \mathrm{MHz}$, MeOD): $\delta 60.5\left(\mathrm{OCH}_{3}\right), 94.7$ (C-8), 99.8 (C-6), 105.9 (C-10), $116.5\left(\mathrm{C}-2^{\prime}\right), 116.5\left(\mathrm{C}-5^{\prime}\right), 122.3$ $\left(\mathrm{C}-6^{\prime}\right), 123.0\left(\mathrm{C}-1^{\prime}\right), 139.7$ (C-3), $146.5\left(\mathrm{C}-3^{\prime}\right), 150.2$ (C-2), $150.0\left(\mathrm{C}-4^{\prime}\right), 158.5$ (C-9), 163.1 (C-5), 166.0 (C-7). ESI-MS (negative mode): $m / z 315$ [M-H] ${ }^{-}\left(\mathrm{C}_{16} \mathrm{H}_{11} \mathrm{O}_{7}\right)$.

6-Methoxymyricetin 3,4'-dimethyl ether (compound III, yellow powder $(4.0 \mathrm{mg})$ ): ${ }^{1} \mathrm{H}$ NMR (400 MHz, MeOD): $\delta 3.81\left(\mathrm{~s}, 3 \mathrm{H}, 3-\mathrm{OCH}_{3}\right) ; 3.89$ (s, 3H, 6- $\left.\mathrm{OCH}_{3}\right) ; 3.90\left(\mathrm{~s}, 3 \mathrm{H}, 4^{\prime}-\mathrm{OCH}_{3}\right)$; 6.52 (s, 1H, H-8); 7.19 (s, 1H, H-2'); 7.19 (s, 1H, H-6 $\left.{ }^{\prime}\right) .{ }^{13} \mathrm{C}$ NMR (100 MHz, MeOD): $\delta 60.7$ $\left(\mathrm{OCH}_{3}\right), 60.8\left(\mathrm{OCH}_{3}\right), 61.0\left(\mathrm{OCH}_{3}\right), 95.0(\mathrm{C}-8), 106.4(\mathrm{C}-10), 109.2\left(\mathrm{C}-2^{\prime}\right), 109.2\left(\mathrm{C}-6^{\prime}\right), 127.0$ $\left(\mathrm{C}-1^{\prime}\right), 132.7$ (C-6), $139.6\left(\mathrm{C}-4^{\prime}\right), 140.1(\mathrm{C}-3), 152.0\left(\mathrm{C}-3^{\prime}\right), 152.0\left(\mathrm{C}-5^{\prime}\right), 153.9(\mathrm{C}-9), 157.5(\mathrm{C}-2)$, 158.9 (C-7), 180.5 (C-4). ESI-MS (negative mode): $m / z 375[\mathrm{M}-\mathrm{H}]^{-}\left(\mathrm{C}_{18} \mathrm{H}_{15} \mathrm{O}_{9}\right)$.

6-Methoxymyricetin 3,3' $4^{\prime}$-trimethyl ether (compound IV, yellow powder (1.3 mg)): ${ }^{1} \mathrm{H}$ NMR (400 MHz, MeOD): $\delta 3.83$ (s, 3H, 3- $\left.\mathrm{OCH}_{3}\right) ; 3.89$ (s, 3H, 4'- $\left.\mathrm{OCH}_{3}\right) ; 3.89$ (s, 3H, $\left.6-\mathrm{OCH}_{3}\right) ; 3.93\left(\mathrm{~s}, 3 \mathrm{H}, 5^{\prime}-\mathrm{OCH}_{3}\right) ; 6.54(\mathrm{~s}, 1 \mathrm{H}, \mathrm{H}-8) ; 7.30\left(\mathrm{~s}, 1 \mathrm{H}, \mathrm{H}-2^{\prime}\right) ; 7.30\left(\mathrm{~s}, 1 \mathrm{H}, \mathrm{H}-6^{\prime}\right) .{ }^{13} \mathrm{C}$ NMR (100 MHz, MeOD): $\delta 55.2\left(\mathrm{OCH}_{3}\right), 59.4\left(\mathrm{OCH}_{3}\right), 59.6\left(\mathrm{OCH}_{3}\right), 59.6\left(\mathrm{OCH}_{3}\right), 93.7(\mathrm{C}-8)$, $103.9\left({\mathrm{C}-6^{\prime}}^{\prime}\right), 105.1$ (C-10), $109.6\left(\mathrm{C}-2^{\prime}\right), 125.5\left({\left.\mathrm{C}-1^{\prime}\right)}^{\prime}, 131.1(\mathrm{C}-6), 138.6(\mathrm{C}-3), 139.0\left(\mathrm{C}-4^{\prime}\right), 150.5\right.$ 
(C-3'), 152.7 (C-9), 153.2 (C-5'), 155.8 (C-2), 157.9 (C-7), 179.0 (C-4). ESI-MS (negative mode): $m / z 389[\mathrm{M}-\mathrm{H}]^{-}\left(\mathrm{C}_{19} \mathrm{H}_{17} \mathrm{O}_{9}\right)$.

Myricetin 3,3' $3^{\prime} 4^{\prime}$-trimethyl ether (compound $\mathrm{V}$, yellow powder $(1.3 \mathrm{mg})$ ): ${ }^{1} \mathrm{H}$ NMR (400 MHz, MeOD): $\delta 3.83\left(\mathrm{~s}, 3 \mathrm{H}, 3-\mathrm{OCH}_{3}\right) ; 3.89\left(\mathrm{~s}, 3 \mathrm{H}, 4^{\prime}-\mathrm{OCH}_{3}\right) ; 3.93\left(\mathrm{~s}, 3 \mathrm{H}, 5^{\prime}-\mathrm{OCH}_{3}\right)$; $6.23(\mathrm{~s}, 1 \mathrm{H}, \mathrm{H}-6) ; 6.43(\mathrm{~s}, 1 \mathrm{H}, \mathrm{H}-8) ; 7.30\left(\mathrm{~d}, J=2.1 \mathrm{~Hz}, 1 \mathrm{H}, \mathrm{H}-2^{\prime}\right) ; 7.30(\mathrm{~d}, J=2.1 \mathrm{~Hz}, 1 \mathrm{H}$, H-6 $\left.{ }^{\prime}\right) .{ }^{13} \mathrm{C}$ NMR $(100 \mathrm{MHz}, \mathrm{MeOD}): \delta 55.2\left(\mathrm{OCH}_{3}\right), 59.4\left(\mathrm{OCH}_{3}\right), 59.6\left(\mathrm{OCH}_{3}\right), 93.5(\mathrm{C}-8)$, 98.6 (C-6), $103.9\left(\mathrm{C}-6^{\prime}\right), 109.6\left(\mathrm{C}-2^{\prime}\right), 125.8\left(\mathrm{C}-1^{\prime}\right), 138.6(\mathrm{C}-3), 139.0\left(\mathrm{C}-4^{\prime}\right), 150.5\left(\mathrm{C}-3^{\prime}\right), 153.2$ $\left(\mathrm{C}-5^{\prime}\right), 155.8$ (C-2). ESI-MS (negative mode): $\mathrm{m} / z 359$ [M-H] ${ }^{-}\left(\mathrm{C}_{18} \mathrm{H}_{15} \mathrm{O}_{8}\right)$.

\subsection{Statistical Analysis}

GraphPad Prism V8 Software for Windows (GraphPad, San Diego, CA, USA) was employed for all statistical analyses. The results were analysed and expressed as the means \pm standard deviation (SD) of three different replicates.

\section{Conclusions}

In this study, five secondary metabolites were isolated and characterized from the MeOH90-F fraction of the total extract of $C$. cowellii by means of a combined methodology of NMR and MS analysis. All five are reported here for the first time for both the plant and the genus. Another 16 compounds were tentatively characterized employing UHPLCHRMS. C. cowellii extract was confirmed to have good antifungal activity against a second fungal/yeast panel, while fractions and mixtures of compounds obtained from the bioassayguided fractionation showed acceptable activity specifically against C. glabrata and C. neoformans. These results highlight the possible use of this plant as a natural antifungal and contribute to a better understanding of the phytochemistry and biological activities of the genus Coccoloba. At the same time, they suggest the probable synergistic effect that the combination of different types of polyphenols may show in inhibiting fungal growth.

Supplementary Materials: The following are available online at https://www.mdpi.com/article/ 10.3390/ph14090917/s1, Figure S1: Full MS and MS/MS spectra of compounds 1-30, Figure S2: Tentative fragmentation pathways of some compounds present in the methanol $90 \%$ fraction of $C$. cowellii, Figure S3: Growth environment (municipality of Camagüey, Cuba) and flowering branch of C. cowellii, Figure S4: NMR data of mixture M-6A (compound I and unidentified impurity), Figure S5: NMR data of mixture M-6B (compounds II and III), Figure S6: NMR data of mixture M-6C (compounds IV and V), Figure S7: Flash chromatogram of the methanol 90\% fraction, Tables S1-S5: First 10 SMART 2.1 results for the compounds of mixtures M-6A, M-6B, and M-6C.

Author Contributions: D.M., J.C.E.-A., E.M.P., A.C., L.P. and P.C. designed the research and analysed the data; D.M., E.T., K.F. and L.P. performed the phytochemical studies; D.M., P.C. and A.M. performed the antifungal and cytotoxicity assays; D.M., J.C.E.-A., E.M.P., A.C., L.P. and P.C. wrote the paper. All authors have read and agreed to the published version of the manuscript.

Funding: This research was funded by VLIR-TEAM, grant number CU2017TEA433A102 and VLIRIUC, grant number CU2019IUC030A105-77143.

Institutional Review Board Statement: Not applicable.

Informed Consent Statement: Not applicable.

Data Availability Statement: The data presented in this study are available in Supplementary Materials.

Conflicts of Interest: The authors declare no conflict of interest. The funders had no role in the design of the study; in the collection, analyses, or interpretation of data; in the writing of the manuscript or in the decision to publish the results.

Sample Availability: Samples of the compounds are not available from the authors. 


\section{References}

1. Fisher, M.C.; Hawkins, N.J.; Sanglard, D.; Gurr, S.J. Worldwide emergence of resistance to antifungal drugs challenges human health and food security. Science 2018, 360, 739-742. [CrossRef]

2. Enoch, D.A.; Yang, H.; Aliyu, S.H.; Micallef, C. The Changing Epidemiology of Invasive Fungal Infections. Hum. Fungal Pathog. Identif. 2017, 1508, 17-65. [CrossRef]

3. Brown, G.D.; Denning, D.W.; Gow, N.A.R.; Levitz, S.M.; Netea, M.G.; White, T.C. Hidden killers: Human fungal infections. Sci. Transl. Med. 2012, 4, 165rv13. [CrossRef] [PubMed]

4. Pfaller, M.A.; Diekema, D.J.; Turnidge, J.D.; Castanheira, M.; Jones, R.N. Twenty Years of the SENTRY Antifungal Surveillance Program: Results for Candida Species from 1997-2016. Open Forum Infect. Dis. 2019, 6, S79-S94. [CrossRef]

5. de Almeida, R.F.M.; Santos, F.C.; Marycz, K.; Alicka, M.; Krasowska, A.; Suchodolski, J.; Panek, J.J.; Jezierska, A.; Starosta, R. New diphenylphosphane derivatives of ketoconazole are promising antifungal agents. Sci. Rep. 2019, 9, 1-14. [CrossRef]

6. Lee, Y.; Puumala, E.; Robbins, N.; Cowen, L.E. Antifungal Drug Resistance: Molecular Mechanisms in Candida albicans and beyond. Chem. Rev. 2020, 121, 3390-3411. [CrossRef]

7. Newman, D.J.; Cragg, G.M. Natural Products as Sources of New Drugs over the Nearly Four Decades from 01/1981 to 09/2019. J Nat. Prod. 2020, 83, 770-803. [CrossRef] [PubMed]

8. Méndez, D.; Escalona-Arranz, J.C.; Foubert, K.; Matheeussen, A.; Van der Auwera, A.; Piazza, S.; Cuypers, A.; Cos, P.; Pieters, L. Chemical and Pharmacological Potential of Coccoloba cowellii, an Endemic Endangered Plant from Cuba. Molecules 2021, $26,935$. [CrossRef]

9. Vukics, V.; Guttman, A. Structural characterization of flavonoid glycosides by multi-stage mass spectrometry. Mass Spectrom. Rev. 2008, 29, 221-235. [CrossRef]

10. Morreel, K.; Dima, O.; Kim, H.; Lu, F.; Niculaes, C.; Vanholme, R.; Dauwe, R.; Goeminne, G.; Inzé, D.; Messens, E.; et al. Mass Spectrometry-Based Sequencing of Lignin Oligomers. Plant Physiol. 2010, 153, 1464-1478. [CrossRef]

11. Morreel, K.; Kim, H.; Lu, F.; Dima, O.; Akiyama, T.; Vanholme, R.; Niculaes, C.; Goeminne, G.; Inze, D.; Messens, E.; et al. Mass Spectrometry-Based Fragmentation as an Identification Tool in Lignomics. Anal. Chem. 2010, 82, 8095-8105. [CrossRef]

12. Kiyota, E.; Mazzafera, P.; Sawaya, A.C.H.F. Analysis of Soluble Lignin in Sugarcane by Ultrahigh Performance Liquid Chromatography-Tandem Mass Spectrometry with a Do-It- Yourself Oligomer Database. Anal. Chem. 2012, 84, 7015-7020. [CrossRef] [PubMed]

13. Zhang, J.-Y.; Wang, F.; Zhang, H.; Lu, J.-Q.; Qiao, Y.-J. Rapid Identification of Polymethoxylated Flavonoids in Traditional Chinese Medicines with a Practical Strategy of Stepwise Mass Defect Filtering Coupled to Diagnostic Product Ions Analysis based on a Hybrid LTQ-Orbitrap Mass Spectrometer. Phytochem. Anal. 2014, 25, 405-414. [CrossRef]

14. El-Kawe, B.M.A. A Pharmacognostical Study of Coccoloba peltata Schott Family Polygonaceae; Cairo University: Cairo, Egypt, 2019.

15. Nafady, A.; Ibraheim, Z.; Abd El-kader, A.; Ahmed, A. Xanthone and lignan glycosides from the aerial parts of Polygonum bellardii all growing in Egypt. Pharmacogn. Mag. 2013, 9, 135. [CrossRef] [PubMed]

16. Lei, J.; Yao, N.; Wang, K.W. Phytochemical and chemotaxomic study on Polygonum perfoliatum L. Biochem. Syst. Ecol. 2013, 48, 186-188. [CrossRef]

17. Wang, K.W.; Zhu, J.R.; Shen, L.Q. A new lignan with anti-tumour activity from Polygonum perfoliatum L. Nat. Prod. Res. 2013, 27, 568-573. [CrossRef]

18. Cong, H.J.; Zhang, S.W.; Zhang, C.; Huang, Y.J.; Xuan, L.J. A novel dimeric procyanidin glucoside from Polygonum aviculare. Chin. Chem. Lett. 2012, 23, 820-822. [CrossRef]

19. Rokaya, M.B.; Münzbergová, Z.; Timsina, B.; Bhattarai, K.R. Rheum australe D. Don: A review of its botany, ethnobotany, phytochemistry and pharmacology. J. Ethnopharmacol. 2012, 141, 761-774. [CrossRef]

20. Odonbayar, B.; Murata, T.; Batkhuu, J.; Yasunaga, K.; Goto, R.; Sasaki, K. Antioxidant Flavonols and Phenolic Compounds from Atraphaxis frutescens and Their Inhibitory Activities against Insect Phenoloxidase and Mushroom Tyrosinase. J. Nat. Prod. 2016, 79, 3065-3071. [CrossRef]

21. Huang, G.H.; Gao, Y.; Wu, Z.J.; Yang, Y.; Huang, D.D.; Chen, W.S.; Sun, L.N. Chemical constituents from Polygonum capitatum Buch-Ham. ex D. Don. Biochem. Syst. Ecol. 2015, 59, 8-11. [CrossRef]

22. Chung, H.S.; Chang, L.C.; Lee, S.K.; Shamon, L.A.; Van Breemen, R.B.; Mehta, R.G.; Farnsworth, N.R.; Pezzuto, J.M.; Kinghorn, A.D. Flavonoid constituents of Chorizanthe diffusa with potential cancer chemopreventive activity. J. Agric. Food Chem. 1999, 47, 36-41. [CrossRef] [PubMed]

23. Gao, Y.; Su, Y.; Yan, S.; Wu, Z.; Zhang, X.; Wang, T.; Gao, X. Hexaoxygenated Flavonoids from Pteroxygonum giraldii. Nat. Prod. Commun. 2010, 5, 223-226. [CrossRef] [PubMed]

24. Xiao, H.; Rao Ravu, R.; Tekwani, B.L.; Li, W.; Liu, W.B.; Jacob, M.R.; Khan, S.I.; Cai, X.; Peng, C.Y.; Khan, I.A.; et al. Biological evaluation of phytoconstituents from Polygonum hydropiper. Nat. Prod. Res. 2017, 31, 2053-2057. [CrossRef]

25. Datta, B.K.; Datta, S.K.; Rashid, M.A.; Nash, R.J.; Sarker, S.D. A sesquiterpene acid and flavonoids from Polygonum viscosum. Phytochemistry 2000, 54, 201-205. [CrossRef]

26. Maury, G.L.; Rodríguez, D.M.; Hendrix, S.; Arranz, J.C.E.; Boix, Y.F.; Pacheco, A.O.; Díaz, J.G.; Morris-Quevedo, H.J.; Dubois, A.F.; Aleman, E.I.; et al. Antioxidants in Plants: A Valorization Potential Emphasizing the Need for the Conservation of Plant Biodiversity in Cuba. Antioxidants 2020, 9, 1048. [CrossRef]

27. Lallemand, J.Y.; Duteil, M. 13C n.m.r. spectra of quercetin and rutin. Org. Magn. Reson. 1977, 9, 179-180. [CrossRef] 
28. Schwingel, L.C.; Schwingel, G.O.; Storch, N.; Barreto, F.; Bassani, V.L. 3-O-Methylquercetin from organic Nicotiana tabacum L. trichomes: Influence of the variety, cultivation and extraction parameters. Ind. Crops Prod. 2014, 55, 56-62. [CrossRef]

29. Rabesa, Z.A.; Voirin, B. ouveaux aglycones flavoniques O-methyles derives de la mearnsetine chez Alluaudia ascendens. Phytochemistry 1979, 18, 360-362. [CrossRef]

30. Ayanoglu, E.; Ulubelen, A.; Clark, W.D.; Brown, G.K.; Kerr, R.R.; Mabry, T.J. Myricetin and quercetin methyl ethers from Haplopappus integerrimus var. Punctatus. Phytochemistry 1981, 20, 1715-1717. [CrossRef]

31. Mai, L.H.; Chabot, G.G.; Grellier, P.; Quentin, L.; Dumontet, V.; Poulain, C.; Espindola, L.S.; Michel, S.; Vo, H.T.B.; Deguin, B.; et al. Antivascular and anti-parasite activities of natural and hemisynthetic flavonoids from New Caledonian Gardenia species (Rubiaceae). Eur. J. Med. Chem. 2015, 93, 93-100. [CrossRef]

32. Fang, N.; Leidig, M.; Mabry, T.J. Fifty-one flavonoids from Gutierrezia microcephala. Phytochemistry 1986, 25, 927-934. [CrossRef]

33. Rabesa, Z.A.; Voirin, B. Deux nouveaux aglycones flavoniques isolés de Decaryiamada gascariensis. Phytochemistry 1980, $19,710-711$. [CrossRef]

34. Alexander, B.D.; Johnson, M.D.; Pfeiffer, C.D.; Jiménez-Ortigosa, C.; Catania, J.; Booker, R.; Castanheira, M.; Messer, S.A.; Perlin, D.S.; Pfaller, M.A. Increasing echinocandin resistance in Candida glabrata: Clinical failure correlates with presence of FKS mutations and elevated minimum inhibitory concentrations. Clin. Infect. Dis. 2013, 56, 1724-1732. [CrossRef]

35. Al Aboody, M.S.; Mickymaray, S. Anti-Fungal Efficacy and Mechanisms of Flavonoids. Antibiotics 2020, 9, 45. [CrossRef]

36. Wu, T.; Cheng, D.; He, M.; Pan, S.; Yao, X.; Xu, X. Antifungal action and inhibitory mechanism of polymethoxylated flavones from Citrus reticulata Blanco peel against Aspergillus niger. Food Control 2014, 35, 354-359. [CrossRef]

37. Gadetskaya, A.V.; Tarawneh, A.H.; Zhusupova, G.E.; Gemejiyeva, N.G.; Cantrell, C.L.; Cutler, S.J.; Ross, S.A. Sulfated phenolic compounds from Limonium caspium: Isolation, structural elucidation, and biological evaluation. Fitoterapia 2015, 104, 80-85. [CrossRef]

38. Mangoyi, R.; Midiwo, J.; Mukanganyama, S. Isolation and characterization of an antifungal compound 5-hydroxy-7,4'dimethoxyflavone from Combretum zeyheri. BMC Complement. Altern. Med. 2015, 15, 1-11. [CrossRef]

39. Yenjai, C.; Prasanphen, K.; Daodee, S.; Wongpanich, V.; Kittakoop, P. Bioactive flavonoids from Kaempferia parviflora. Fitoterapia 2004, 75, 89-92. [CrossRef] [PubMed]

40. Fonzi, W.A.; Irwin, M.Y. Isogenic strain construction and gene mapping in Candida albicans. Genetics 1993, 134, 717-728. [CrossRef] [PubMed]

41. Ramage, G.; Robertson, S.N.; Williams, C. Strength in numbers: Antifungal strategies against fungal biofilms. Int. J. Antimicrob. Agents 2014, 43, 114-120. [CrossRef]

42. Shahzad, M.; Sherry, L.; Rajendran, R.; Edwards, C.A.; Combet, E.; Ramage, G. Utilising polyphenols for the clinical management of Candida albicans biofilms. Int. J. Antimicrob. Agents 2014, 44, 269-273. [CrossRef] [PubMed]

43. Caesar, L.K.; Cech, N.B. Synergy and antagonism in natural product extracts: When $1+1$ does not equal 2. Nat. Prod. Rep. 2019, 36, 869-888. [CrossRef]

44. Nothias, L.F.; Nothias-Esposito, M.; Da Silva, R.; Wang, M.; Protsyuk, I.; Zhang, Z.; Sarvepalli, A.; Leyssen, P.; Touboul, D.; Costa, J.; et al. Bioactivity-Based Molecular Networking for the Discovery of Drug Leads in Natural Product Bioassay-Guided Fractionation. J. Nat. Prod. 2018, 81, 758-767. [CrossRef] [PubMed]

45. Cushnie, T.P.T.; Lamb, A.J. Antimicrobial activity of flavonoids. Int. J. Antimicrob. Agents 2005, 26, 343-356. [CrossRef] [PubMed]

46. de Freitas, A.L.D.; Kaplum, V.; Rossi, D.C.P.; da Silva, L.B.R.; Melhem, M. de S.C.; Taborda, C.P.; de Mello, J.C.P.; Nakamura, C.V.; Ishida, K. Proanthocyanidin polymeric tannins from Stryphnodendron adstringens are effective against Candida spp. isolates and for vaginal candidiasis treatment. J. Ethnopharmacol. 2018, 216, 184-190. [CrossRef] [PubMed]

47. Da Silva, C.R.; De Andrade Neto, J.B.; De Sousa Campos, R.; Figueiredo, N.S.; Sampaio, L.S.; Magalhães, H.I.F.; Cavalcanti, B.C.; Gaspar, D.M.; De Andrade, G.M.; Lima, I.S.P.; et al. Synergistic effect of the flavonoid catechin, quercetin, or epigallocatechin gallate with fluconazole induces apoptosis in Candida tropicalis resistant to fluconazole. Antimicrob. Agents Chemother. 2014, 58, 1468-1478. [CrossRef] [PubMed]

48. Han, Y. Synergic anticandidal effect of epigallocatechin-O-gallate combined with amphotericin B in a murine model of disseminated candidiasis and its anticandidal mechanism. Biol. Pharm. Bull. 2007, 30, 1693-1696. [CrossRef] [PubMed]

49. Cos, P.; Vlietinck, A.J.; Berghe, D.V.; Maes, L. Anti-infective potential of natural products: How to develop a stronger in vitro "proof-of-concept". J. Ethnopharmacol. 2006, 106, 290-302. [CrossRef]

50. de Cremer, K.; Lanckacker, E.; Cools, T.L.; Bax, M.; de Brucker, K.; Cos, P.; Cammue, B.P.A.; Thevissen, K. Artemisinins, new miconazole potentiators resulting in increased activity against Candida albicans biofilms. Antimicrob. Agents Chemother. 2015, 59, 421-426. [CrossRef] 